\title{
医用金属材料の腐食亡生体反応
}

\author{
遠藤一彦*, 松田浩一 ${ }^{* *}$, 安彦善裕 ${ }^{* * *}$, 大野弘機 ${ }^{*}$, 賀来 亨 ${ }^{* * *}$ \\ * 北海道医療大学歯学部歯科理工学講座 \\ ** 北海道医療大学歯学部歯科保存学第二講座 \\ *** 北海道医療大学歯学部口腔病理学講座
}

\section{Degradation of Metallic Surgical Implants and Biological Responses}

\author{
Kazuhiko Endo*, Koichi Matsuda**, Yoshihiro Abiko*** \\ Hiroki Ohno* and Tohru Kaku*** \\ * Department of Dental Materials Science, School of Dentistry, \\ Health Sciences University of Hokkaido \\ ** Department of Operative Dentistry, School of Dentistry, \\ Health Sciences University of Hokkaido \\ *** Department of Oral Pathology, School of Dentistry, \\ Health Sciences University of Hokkaido
}

\begin{abstract}
Metallic surgical implants have been widely used in orthopedics and dentistry. This paper reviews the biodegradation of metallic implants and its local and systemic effects on patients. The review discusses typical damage of $316 \mathrm{~L}$ stainless steel, Co-Cr alloy, commercially pure $\mathrm{Ti}$, and Ti-based alloy implants due to corrosion and wear and factors affecting the biodegradation of these implants. Macrophage mediation of cellular and humoral regulatory pathways in inflammatory and immune responses to metallic ions and wear debris released from the implant is summarized. Implant-related factors influencing the susceptibility to local infection are also discussed.
\end{abstract}

Key words : metallic implant, corrosion, wear, inflammation, immune response, macrophage

\section{1.はじめに}

インプラントとは，失われた解剖学的形態および生体 機能を回復するために, 生体内に埋植して用いる人工デ バイスである。生体硬組織に埋植されるインプラント は，高い外力を支持しなければならないことから，主に 金属材料を用いて作製されている。整形外科領域では, 股関節や膝関節を人工関節で置換するインプラント治療 が一般的に行われており，その数は世界中で年間 30 万 〜 40 万症例に達している ${ }^{1)}$ 。歯科領域においても，歯 牙を欠損した顎骨内に人工歯根を埋植し, 補綴用上部構 造物を支持させるインプラント治療が，21 世紀におけ る有効な歯科治療法の一つとして脚光を浴びている。

インプラント治療における最大の問題は, 生体は埋植 された金属材料を非自己すなわち異物として認識しここ

*,**,*** 干061-02 北海道石狩郡当別町金沢 1757 (1757, Kanazawa, Tobetsu-cho, Ishikari-gun, Hokkaido, 061-02 Japan)
れを排除するように反応することである。すなわち，金 属インプラントは, 生体内で安定な状態で機能を果たし ているわけではない。インプラント周囲の生体組織は, 常に炎症を起こしやすい状態にある。何らかの刺激によ り炎症反応が生じると，インプラントは異物として速や かに排除される運命となる。すなわち，炎症をともなっ た一連の異物処理反応の結果, 人工歯根の動摇や人工関 節の緩みが臨床的な症状として見られるようになる。イ ンプラントの周囲組織に炎症を惹起する要因として, （1）金属の腐食生成物や摩耗粉による刺激，（2）しきい 值を越えた外力，（3）細菌感染などが挙げられる。した がって, 生体適合性の高い金属インプラントを開発しよ うとする場合, 生体と力学的に適合したデザインの設計 と材料の選択を行った上で，生体内における金属の劣化 とそれに対する生物学的反応を良く理解し，それらを制 御することが必要である。

本稿では, インプラントに用いられる金属材料と生体 


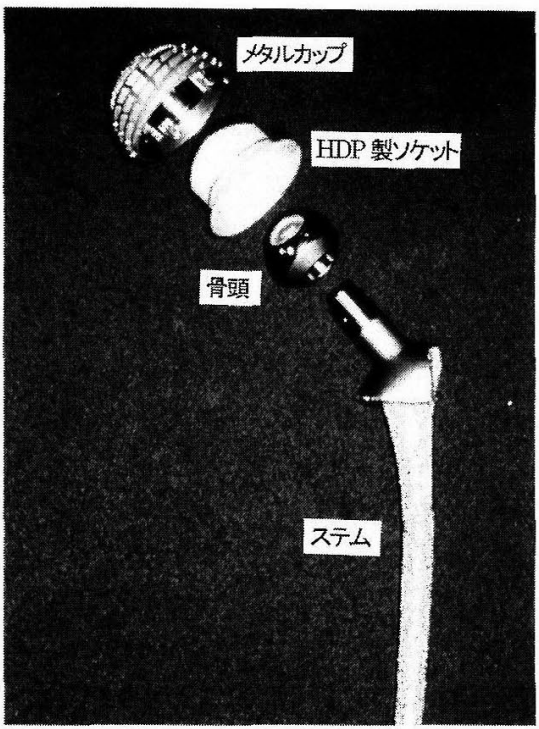

図 1 骨頭交換タイプの人工股関節

の相互作用について述べる。特に，金属材料の生体内に おける少化機構と，それに対する異物性生体反応につい て，現在までに得られている知見を整理して解説する。 また, 生体内における金属インプラントの劣化反応と細 菌感染の関連についても言及する。

\section{2. インプラント用金属材料}

整形外科領域で実用化されている金属材料は，ステン レス鋼（SUS $316 \mathrm{~L})$ ，バイタリウム (Co-Cr 合金)， チタン合金（Ti-6Al-4V）である2。これらの金属材 料は, 補経用 (人工骨, 人工関節) や骨固定用（骨プレー ト，ねじ，ワイヤー）として用いられている。一例とし て，図 1 に骨頭交換タイプの人工股関節を示す。ステム は大腿骨側に，金属でバッキングされた高密度ポリエチ レン (HDP) 製ソケットは寛骨臼側に埋植される。人 工関節を骨に固着する方法として, 骨セメント（主成分 MMA）を使用するセメント方式と新生する骨により固 着させる非セメント方式がある。非セメント方式におい ては，骨に接触する部分の表面は，骨組織の ingrowth により結合を強固にするために，多孔質にした り，あるいは溝を付与したりしている。

図 2 に菌科領域で用いられている代表的な人工茵根を 示す。デザインは，スクリュータイプおよびシリンダー タイプが主流である。材料として，多くの製品で純チ夕 ン $(\mathrm{Ti})$ が用いられている。一部では, チタン合金 （Ti-6Al-4V，NiTi 形状記憶合金）も用いられている。 表面处理として，骨との機械的結合を目的としたチタン のプラズマコーティングやチタン合金粉末の焼結, 耐食

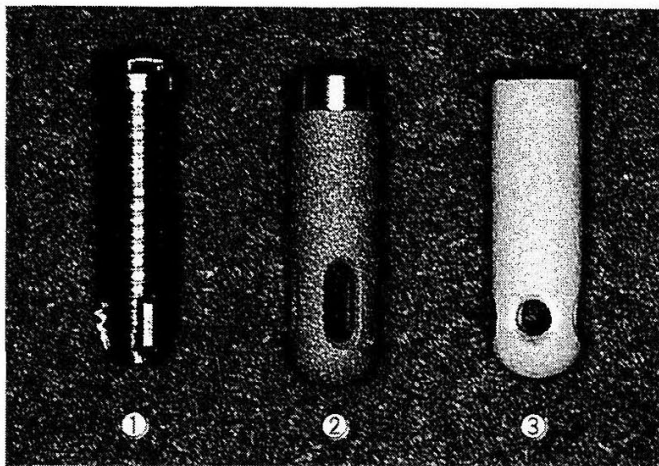

図 2 人工歯根
(1)スクリュータイプ
(2)シリンダータイプ (Ti プラズマ溶射)
(3)シリンダータイプ (HA プラズマ溶射)

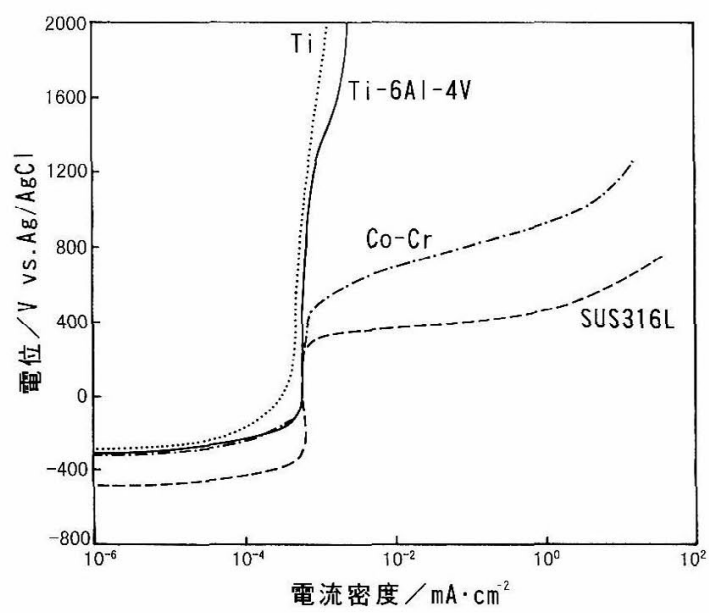

図 3 インプラント用金属材料の生理食塩水中における アノード分極曲線

性の向上を目的とした陽極酸化処理などが施されてい る。また，骨組織に対して良好な親和性を示すハイドロ キシアパタイト（HA）を表面にプラズマ熔射した製品 も市販されている。

\section{3. インプラント用金属材料の In vitroにおける耐食} 性

図 3 にインブラントに使用されている金属の生理食塩 水 $(0.9 \% \mathrm{NaCl}$ 溶液 $)$ 中に抢けるアノード分極井線を ホす。 $\mathrm{Ti}$ および $\mathrm{Ti}$ 合金の耐食性は, $\mathrm{Co}-\mathrm{Cr}$ 合金や SUS 316 L と比較すると非常に良い。Ti および Ti 合 金の優れた生休適合性は，この高い耐食性に基づいてい る。SUS 316 L は, 加工性と経済性に優れているが, 他の合金と比べて耐食性は低い。また，生体内で局部腐 食を起こしやすいため，その使用頻度は隇少する傾向に 


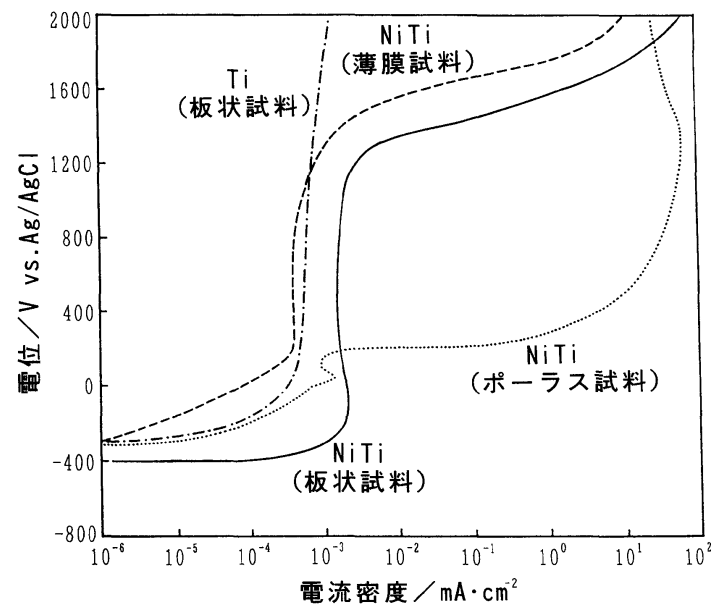

図 4 表面性状の異なるチタン合金のアノード分極曲線

ある。

図 4 に NiTi 合金の表面性状と耐食性の関係を示 す3)。粉末合金を焼成して作製したポーラスな合金（平 均細孔径 $300 \mu \mathrm{m}$ ，気孔率 50\%）では，不働態領域がほ とんど認められない。一方，スパッタリング法を用いて シリコン基盤上に作製した合金薄膜では，鏡面に研磨し た板状試料と比較して, 不働態保持電流密度は低く, 脱 不働態化電位の值は高い。インプラントに用いられてい る金属材料はすべて不働態化合金であり，その表面性状 は耐食性に大きく影響する。現在，骨埋入部の表面を多 孔質にし，骨組織を材料内部に成長させて機械的に結合 させるインプラントが開発されている。しかし，(1) 不 均一な表面形状に基づく高い局部腐食感受性，（2）表面 積の増加に伴う溶出金属量の増加，（3）骨-インプラン 卜界面に発生する応力による金属片の剥離，（4）細菌感 染のリスク増大, などの問題がある。骨との結合を強固 にし，かつインプラント材の腐食を最小限にする効果的 な表面形状の設計，表面処理法の開発が望まれている。

\section{4. インプラント用金属の In vivo における劣化}

\section{1 生体内環境}

生体内は, 常温, 常圧かつ中性であり, 腐食環境亡し ては，䅼やかに見える。しかし，体液は海水に似た無機 塩類を含む電解質溶液であり, 不働態皮膜の安定性に影 響する $\mathrm{Cl}^{-}$を約 $100 \mathrm{ml} / \mathrm{l}$ 含む。また，金属イオンと配 位化合物を形成しやすいアミノ酸やタンパク質を多く含 み，不働態化合金の腐食を加速する ${ }^{4)}$ 。さらに，人工関 節では，体重の数倍に及ぶ荷重が加わる部位もある ${ }^{5)}$ 。 関節摺動部やステムの骨接触面においては, 繰り返し荷 重により摩耗が生じる。これらの事実を考慮すると, 生 体内は，金属インプラントにとって，決して穏やかな環

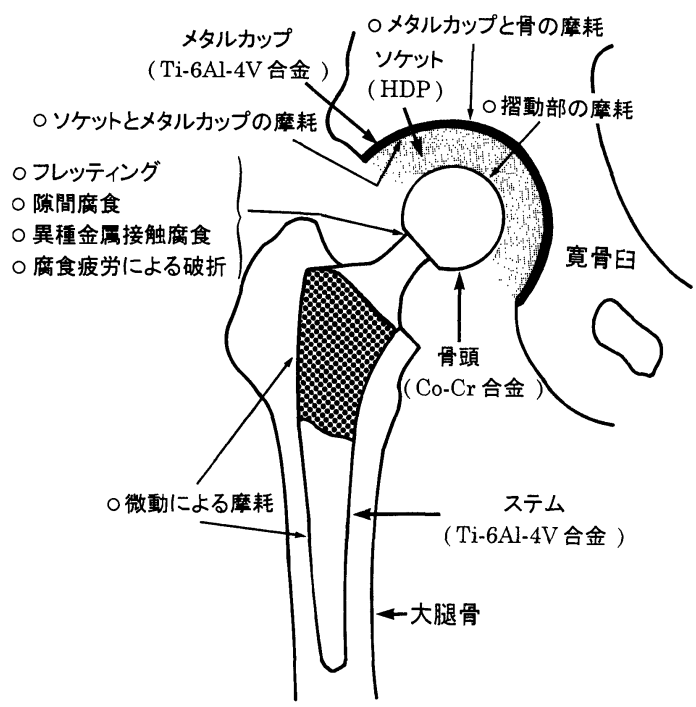

図 5 人工股関節の構造と生体内で劣化の起こりやすい 部位

境ではなく，むしろ非常に厳しい腐食環境と言えよう。

\section{2 生体内における腐食例}

生体内から撤去した人工股関節および骨プレートの腐 食事例は，多数報告されている。人工股関節において, 腐食ならびに摩耗を受けやすい部位をまとめて図 5 に示 す。最も腐食が問題となっている部位は，骨頭交換夕イ プにおける骨頭とステムの接合部位である ${ }^{6)}$ 。テーパー のついたステムのネック部に骨頭をはめ込んでいるた め, 隙間腐食や擦過腐食を受けやすい構造となってい る。また, ステムには, 骨との力学的適合性を考慮し, 弾性率の低い Ti-6Al-4V 合金を用い, 骨頭に耐摩耗性 の良い Co-Cr 合金を用いるタイプも汎用されている。 この場合には，異種金属接触腐食を起こす可能性があ る。In vitro での腐食試験では, Ti-6 Al-4V 合金と $\mathrm{Co}-\mathrm{Cr}$ の接合による異種金属接触腐食は, 大きな問題 とはならないと報告されている7),8)。しかし，実際の臨 床例では，Ti-6 Al-4V 合金製ステムと $\mathrm{Co}-\mathrm{Cr}$ 合金製 骨頭の組み合わせた方式では，35～55\%の抜去インプラ ントにおいて, 骨頭/ネック接触面に腐食の痕跡が認め

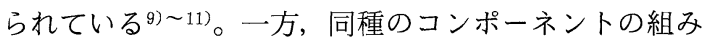
合わせ方式では, 骨頭/ネック接触面の腐食は, 撤去し たインプラントの 9\%以下でしか見られていない11)。異 種コンポーネントの組み合わせにより形成した隙間で は，異種金属の接触およびフレッティングの影響を受け た隙間腐食が生じやすいものと考えられる。ステムと骨 頭とのジャンクションにおけるネック部の腐食疲労によ る破折例も報告されている12)。

関節摺動部では，骨頭とソケットの摩耗が生じる。金 
表 1 金属インプラントを有する患者における金属元素の体内分布（ppm）

\begin{tabular}{|c|c|c|c|c|c|c|c|c|}
\hline インブラントの種類 & 臟器·体液 & Co & $\mathrm{Cr}$ & $\mathrm{Ti}$ & $\mathrm{Al}$ & V & 備考 & 文献 \\
\hline Co-Cr 合金人工股関節 & $\begin{array}{l}\text { 肺 } \\
\text { 堅臓 } \\
\text { 肝臟 } \\
\text { 聘䐟 }\end{array}$ & $\begin{array}{c}0.24 \\
(0.02) \\
0.31 \\
(0.01) \\
0.47 \\
(0.06) \\
0.23 \\
(0.04)\end{array}$ & $\begin{array}{c}0.18 \\
(0.09) \\
0.39 \\
(0.01) \\
0.61 \\
(0.01) \\
0.56 \\
(0.01)\end{array}$ & & & & 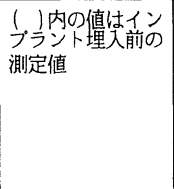 & 39 \\
\hline Co-Cr 合金人工股関節 & $\begin{array}{l}\text { 血中 } \\
\text { 尿中 }\end{array}$ & $\begin{array}{c}0.007 \\
(0.001) \\
0.024 \\
(0.001) \\
\end{array}$ & $\begin{array}{c}0.004 \\
(0.001) \\
0.006 \\
(<0.001)\end{array}$ & & & & 值)内の值は正常 & 34 \\
\hline Ti-6A1-4V 合金人工股関節 & $\begin{array}{l}\text { 血中 } \\
\text { 尿中 }\end{array}$ & & & $\begin{array}{c}0.008 \\
(0.004) \\
0.002 \\
\left(\begin{array}{l}N D\end{array}\right)\end{array}$ & $\begin{array}{c}0.002 \\
(0.002) \\
0.007 \\
(0.006)\end{array}$ & $\begin{array}{c}0.001 \\
(\mathrm{ND}) \\
0.001 \\
(0.001)\end{array}$ & $\begin{array}{l}\text { (゙)内の傎はイン } \\
\text { ブラント有しな } \\
\text { い人で得られた値 }\end{array}$ & 36 \\
\hline
\end{tabular}

属製の骨頭とソケットを使用した場合には，多量の摩耗 粉が放出される。そこで，一般的には高密度ポリエチレ ン (HDP) 製のソケットを金属でバッキングして使用 している。金属骨頭と HDP ソケットの組み合わせで は, 周囲組織に放出される摩耗金属粉の量は，金属同士 で構成された関節面と比較して，およそ $1 / 10$ に減少す る ${ }^{13)}$ 。今日では, さらに低摩擦・低摩耗性関節面の実現 を目指して，セラミックス製骨頭の使用を検討してい る ${ }^{14)}$ 。組織中に金属粉が放出されると，金属の表面積は 増大するため，金属の溶出量は多くなる。また，後で詳 しく述べるように，金属および HDP の摩耗粉を細胞が 貪食すると,一連の組織反応(炎症反応)を引き起こす。 非関節面では，臼蓋側に使用される金属カップとそれを 骨に固定する金属製ねじのフレッティングによる摩耗 や15)，セメント固定の緩んだステムの微動（micro-

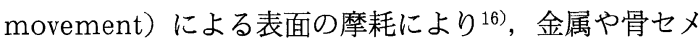
ントの摩耗粉を生じる。表面を多孔質化した非セメント 方式のステムでは，荷重負荷時に，骨-ステム界面に発 生する応力により，表面から金属片が剥離する場合もあ る $^{17), 18)}$ 。

骨プレートでは，プレートねじ止め部における腐食の 事例が報告されている。Cook らは，82 例の撤去したス テンレス製骨プレートを調べ，約 $90 \%$ のプレートにお いて，ねじ止め部の隙間腐食，あるいはプレート表面で の孔食を認めたと報告している ${ }^{19)}$ 。また，腐食の程度と 骨プレートの緩み，ならびに組織反応の程度との間に正 の相関が得られている20)。

\section{3 金属インプラントの劣化にともなう金属元素の 生体内分布}

生体内に金属を埋入すると，腐食あるいは摩耗にとも なって，周囲組織中に金属が放出される。Reuling ら は，家鬼の脊椎傍部筋肉に歯科用 $\mathrm{Ni}-\mathrm{Cr}$ 合金および $\mathrm{Co}-\mathrm{Cr}$ 合金を埋入し，腐食により周囲組織の金属濃度 が上昇することを示した ${ }^{21)}$ 。また，エクテサビらは，
$\mathrm{Ti}$ 合金製ねじ型インプラントを埋入した家鬼の頸骨を 荷電粒子励起 X 線分析法を用いて調べ, インプラント から遠ざかるほご検出される $\mathrm{Ti}$ は減少するが， $5 \mathrm{~mm}$ 離れた骨中においても微量の $\mathrm{Ti}$ を検出している22)。臨 㦿においては, 人工股関節の再置換術の際に，インプラ ント周用に形成された偽関節囊や滑膜などの軟組織にお いて，摩耗により放出された多量の金属粉により着色 し, 慢性炎症を起こしている症例が多数見られてい

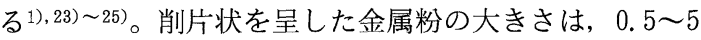
$\mu \mathrm{m}$ である ${ }^{15), 26), 27)}$ 。Haynes らは，人工股関節の周囲 組織に放出される金属粉の量は, Ti-6 Al-4V 合金を使 用した場合には, 組織 $1 \mathrm{~g}$ 当たり平均で約 $5 \times 10^{7}$ 個で あり，耐摩耗性に優れる $\mathrm{Co}-\mathrm{Cr}$ 合金を使用した場合に は, 約 $2.5 \times 10^{6}$ 個と見積もっている28)。また，インプ ラント周囲の組織中には, 金属粉とともに骨セメント (PMMA) や高密度ポリエチレンの摩耗粉（1～200 $\mu \mathrm{m} ）$ 屯存在する ${ }^{15), 29)}$ 。これらの摩耗粉は, 局所の炎症 や局部組織の壊死の原因となるため, 人工股関節の予後 に大きく影響する。症例は極めて少ないが，インプラン 卜部位における腫瘍の形成にインプラントの物理的・化 学的刺激の影響が疑われている例も報告されてい る $^{30) \sim 33)}$ 。

腐食や摩耗により放出される金属は，インプラントの 周囲組織に蓄積するのみならず，一部は全身に運搬され る。人工股関節を有する患者では，表 1 に示しているよ うに血中および尿中の金属濃度が上昇する ${ }^{34) ~ 38) 。 ま ~}$ た，所属リンパ節や肺，腎藏，肝臓および脾臓などの臟 器にも $\mathrm{Ti}, \mathrm{Co}, \mathrm{Cr}$ などの金属が蓄積する ${ }^{26), 39) 。 こ れ ~}$ らの事実を考えると，体内に埋入されたインプラントの 劣化反応は, 全身的な疾患之関わりのある可能性も否定 できないが，その詳細に関しては今後の研究が待たれ る。現在のところ，人工股関節置換術を受けた患者にお いて, リンパ腫や白血病の罹患率が高くなるとの疫学的 データが発表されているに過ぎない311。 


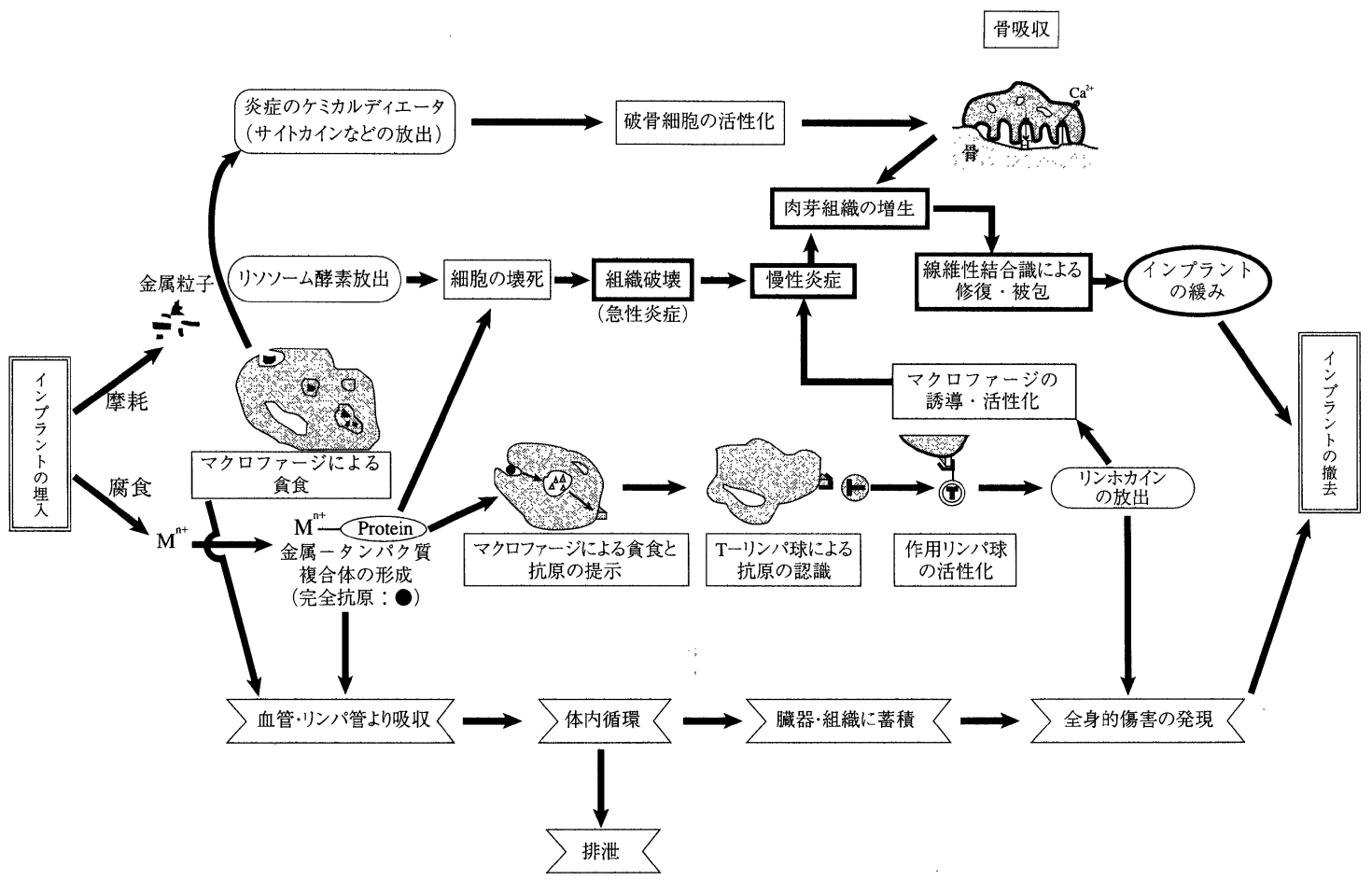

図 6 インプラントの劣化に対する異物性生体反応

\section{5. インプラントの劣化に対する生体の異物性生体反} 応

生体は，インプラントの劣化により生成する刺激のあ る異物を処理し，侵襲部位の修復をはかるために，一連 の炎症反応を惹起する。異物性生体反応は, 図 6 に示す ように，摩耗粉によって生じる非特異的防御反応と，金 属イオンが関与する免疫反応（細胞性免疫）に大別され る。血球細胞の一種であるマクロファージ（大食細胞） は，いずれの生体反応においても中心的な役割を果た す40), 41)。

非特異的防御反応の第一段階は, マクロファージによ る金属摩耗粉（0.5 5 $\mu \mathrm{m}$ ) の細胞内への取り込み（荟 食)である。通常，貪食された細菌や壊死組織などの異 物は, 食胞リソソーム内に存在する各種加水分解酵素に より分解されて処理されるが，金属の摩耗粉は細胞内で 消化処理されない42)。毒性の強い $\mathrm{Co}-\mathrm{Cr}$ 合金の摩耗粉 を領食したマクロファージは，細胞の崩壊にともなっ て，リソソーム酵素を周囲組織に放出する ${ }^{28), 42 \sim 44) 。 こ ~}$ れらの酵素は，宿主の組織を傷害し炎症反応を誘起す る。一方, 毒性の低い Ti-6 Al-4V 合金の摩耗粉を貪食 した場合には，細胞膜の破壊とリソソーム酵素の放出は 起こらない。しかし，取り込んだ金属粉の刺激によりマ クロファージは活性化し，炎症反応のメディエー夕を産

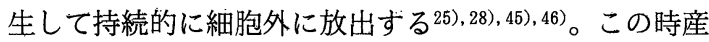

生される prostaglandin $\mathrm{E}_{2}$, interleukin-1, interleukinn-6, tumor necrosis factor などのメディエー 夕は，いずれも破骨細胞などを活性化してインプラント 周囲の骨を破壊・吸収することが知られている11,47〜49)。 骨セメントや HDP 摩耗粉を頜食した場合にも，同様な メディエータを産生し，骨吸収を起こす50),51)。貪食で きない大きな異物粒子の存在下では, マクロファージは 融合し多核の異物巨細胞（径 40～100 $\mu \mathrm{m}$ ）となる（図 7)。異物粒子を取り囲んだ複数の異物巨細胞の周囲に は, 肉芽組織が形成された。さらに線維性組織により包 囲されることにより, 異物を生体から隔離した状態にす る ${ }^{42), 52) 。 ~}$

このように，マクロファージに貪食される粒子状固形 物の性状により, 組織傷害のメカニズムは異なる。しか し，いずれの場合もインプラントは，誘起される一連の 炎症反応の結果, 線維性結合組織により被包され, 骨と の嵌合を失う。この時点で, 疼痛およびインプラントの 緩み（動摇）といった臨床所見が認められ，それらの程 度によっては,インプラントの撤去に至る場合もある。

特異的免疫反応は，溶出した金属イオンにより起こる 遅延型過敏症（金属アレルギー）である53～55)。この反 応は, マクロファージや T リンパ球が関与する典型的 な細胞性免疫反応である。分子量の小さい金属イオン は, 抗原とはなり得ない。しかし, 生体内でキャリア夕 


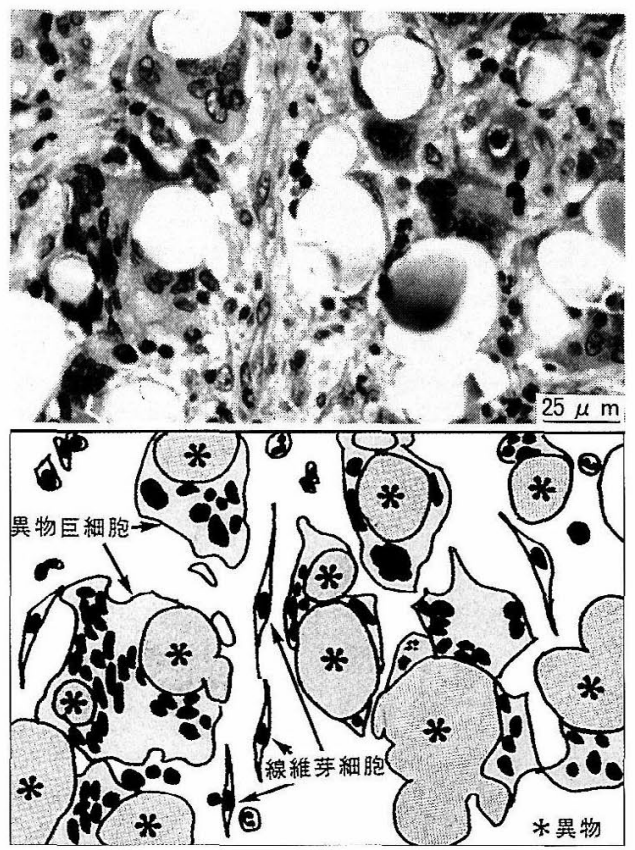

図 7 組織中に存在する異物とその周囲に出現した多核 の異物巨細胞

ンパク質と結合して完全抗原となり，感作性を示すよう になる。図 8 に示すようにマクロファージは金属イオン を含む抗原タンパク質を貪食し, エンドゾーム内でタン パク分解酵素により断片化した抗原ペプチドを自己由来 の分子（MHC class II 分子）とともに細胞膜表面に提 示する40),56)。T-リンパ球は, リンパ組織でマクロファー ジが提示した抗原-MHC 複合体とレセプターを介して 結合し，抗原を認識する57)。その後，リンパ節の中の傍

皮質域で増殖した抗原特異的なTーリンパ球は，全身を 循環し始める。図 6 に示すように末梢の組織で再び抗原 に出会う亡, T-リンパ球は活性化され種々のリンホカ インを放出する。これらのリンホカインの作用により, マクロファージや好酸球がその場に誘導される。マクロ ファージは組織を傷害するライソゾーム酵䒺を放出し, 炎症を誘起する。これらの反応は, 組織中に存在する抗 原が除去されるまで続く。インプラントから持続的に金 属イオンが溶出する場合には, 周囲組織は慢性炎症を起 こし，肉䓆組織の形成を経て線維性の組織により被包さ れる。また，インプラントから溶出した金属イオンが血 流に乗って運搬され，遠隔の皮膚に到達すると，アレル ギー性炎症である湿疹や萇麻疹などを起こすこともあ る。

金属アレルギーを起こす頻度の高い金属は, $\mathrm{Ni}$, $\mathrm{Hg}, \mathrm{Co}, \mathrm{Cr}, \mathrm{Cu}$ である58)。 Ti は経験的にアレルギー 反応を起こさないと言われており，この点では生体材料 として適している。しかし，最近， Ti に対するアレル ギーが疑われる症例も二，三報告されており， $\mathrm{Ti}$ の感 作性に関しては, さらに検討が必要である59)。

インプラントの劣化に対する生体の異物反応を，食細 胞および抗原提示細胞として機能するマクロファージの 役割を中心に述べた。人工股関節においては，非感染性 緩みの原因となる炎症は，コンポーネントの微動による 機械的刺激ならびに放出される摩耗粉による非特異的な 免疫反応により誘起される場合が多いものと考えられ

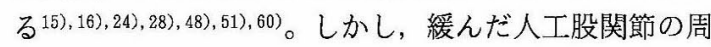
囲組織にアレルギー性炎症が認められた症例も多数報告 されている37),61 65)。French らは, 金属インプラント 周囲組織に見られる炎症の約 $1 / 3$ は, 金属アレルギー が原因であると述べている66)。人工霜 根においては，次に述べる感染による 炎症が，インプラント撤去の原因とな ることが多い。

\section{6. インプラント劣化反応と感染症}

代謝をともなわない人工材料表面 は，生体内において最も細菌感染の起

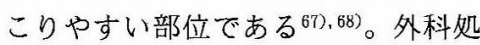
置は無菌手術室で行い, 抗生剤の投与 を併用したとしても，感染のリスクは 皆無ではない。インプラント表面で は, 付着・増殖する細胞により, 組織 が再構築されなければならない。しか し，インナ゚ラント埋入時に, 細菌が細 胞よりも先に表面に付着しコロニーを 形成すると，健全な組織は構築され 
ず, 周囲組織に腫張や疼痛をともなった炎症を生じ, 発 熱などの全身的病変を生じる場合もある ${ }^{69) 。 こ の よ う な ~}$ 早発性の術後感染は, インプラント治療の最も重篤な合 併症の一つである。特に表面がポーラスな構造となって いるインプラントでは, 術後感染のリスクは高(70)。材 料表面を這うように遊走する細胞に対し, 細菌は体液中 を移動して早く細孔内部に到達し，コロニーを形成する ためである。

インプラントの周囲組織に異物反応にともなう慢性炎 症が見られる場合は, 細菌感染のリスクは高くなる。金 属粉を取り込んだマクロファージは, 領食作用を発現す る際に必要な酵素であるグルコース-6-リン酸脱水素酵 素（G6PD）の細胞内濃度が減少しているため, 侵入し た細菌に対する貪食・殺菌機能が低下している43)。ま た，金属粉を貪食したマクロファージの能動的な移動に より，所属リンパ節に金属粉が蓄積すると, リンパ組織 の線維化や壊死が起こる。これらの結果, 局所組織の免 疫力は低下する。もし, 上気道, 尿路系あるいは歯牙や 歯周組織など口腔内の感染病巣から細菌が血行に入り全 身に散布された場合, 免疫力の低下しているインプラン 卜周囲において二次感染を生じやすい。このような遅発 性の感染例として, 歯周炎の治療後, 口腔内常在菌の感 染に起因する炎症により, 人工股関節の埋入部位に疼痛 を生じた症例が報告されている72)。また, 腎臟や肝臟な どの臟器移植を受け, 免疫抑制剂を投与されている患者 は, 人工関節手術を受けた後, 周囲組織で感染を起こし やす(73)。

人工歯根は, 上皮（歯肉）を貫通しており, 特に細菌 の影響を受けやすい構造となっている ${ }^{74)}$ 。粘膜貫通部に おいて, 材料表面に上皮ならびに結合組織が密着して再 生しなければ, 容易に感染し炎症反応を起こす。その結 果, 骨埋入部における骨の吸収, 線維性結合組織の増生 と上皮の哚部増殖が起こると, 人工歯根は動摇し最終的 には生体から排除される。歯科インプラントの成否は, 感染対策にかかっていると言っても過言ではない。

\section{7. 異物性生体反応を考慮した金属インプラント開発 の動向}

耐食性の低い金属材料を生体内に埋入すると, 多量に 溶出する金属イオンの毒性により, 細胞の壊死に引き続 き周囲組織の破壊が起こるであろう。高い耐食性を有す る材料を生体内で用いるのが原則である。このような観 点から, 臨床では, 純 $\mathrm{Ti}$ および $\mathrm{Ti}$ 合金の使用頻度が 高くなっている。現在使用されている Ti-6 Al-4V 合金 の生体適合性をさらに向上させるため, 生体為害性を有 する $\mathrm{Al}$ や V などの元素を除いた, Ti-13Zr-13Nb 合 金や Ti-15Zr-4Nb-4Ta-0.2 Pd 合金が新たに開発され
ている75)。

インプラントが重篤な異物性炎症反応を誘起すること なく, 生体内で安定に存在するためには, 材料の摩耗を 最小限に押さえる工夫が必要である。骨セメントとステ 么の接着性を向上させ，摩耗粉の放出を抑制するため に，接着性モノマー（4-META）を含有したアクリル レジンで金属製ステムをプリコーティングする手法が提 案されている76)。また, ダイヤモンド微粒子はマクロ ファージを活性化しないことに着目し，ダイヤモンド薄 膜による人工股関節表面のコーティングも検討されてい る77)。

\section{8. おわりに}

本稿では, 生体内における金属の劣化とそれに対する 異物性生体反応について概説した。異物性生体反応につ いては, 病理学的にも明確に位置づけられておらず, 不 明な点も数多く残されている。今後, インプラントと生 体組織の間に安定な界面を構築し，インプラントを長期 間機能させるためには, 材料科学のみならず免疫学, 毒 理学, 薬理学, 病理学など広い分野の知識と技術を結集 してアプローチする必要があるものと考えられる。紙面 の都合上紹介できなかったが，金属インプラント表面を 機能化し, 生体組織を積極的に構築するための研究も精 力的に行われていることを付け加えておく ${ }^{74), 78 \sim 80) 。 ~}$

(1997 年 6 月 2 日受理)

\section{文献}

1) S. R. Goldring, A. L. Schiller, M. Roelke, C. M. Rourke, D. A. O'Neill and W. H. Harris : J. Bone and Joint Surg., 65-A, 575 (1983).

2 ）浜中人士 : 日本金属学会報, 23，238（1984）.

3 ) Y. Abiko, K. Endo, R. Sachdeva, Y. Araki, H. Ohno and T. Kaku : J. Soci. Dent. Products Jpn., 9, 9 (1996).

4 ) K. Endo: Dent. Mater. J., 14, 199 (1995).

5 ) 筏義人編 :「バイオマテリアル入門」初版, p. 126, 学会出版センター (1993).

6 ) E. B. Mathiesen, J. U. Lindgren, G. G. A. Blomgren and F. P. Reinholt : J. Bone and Joint Surg., 73-B, 569 (1991).

7 ) L. C. Lucas, R. A. Buchanan and J. E. Lemons : J. Biomed. Mater. Res., 15, 731 (1981).

8 ) C. D. Griffin, R. A. Buchanan and J. E. Lemons : J. Biomed. Mater. Res., 17, 489 (1983).

9) J. P. Collier; V. A. Surprenant, R. E. Jensen and M. B. Mayor : Clin. Orthop., [271] 305 (1991)

10) J. P. Collier, V: A. Surprenant, R. E. Jensen, M. B. Mayor and H. P. Surprenant: J. Bone and Joint Surg., 74-B, 511 (1992). 
11) S. D. Cook, R. L. Barrack and A. J. T. Clemow : J. Bone and Joint Surg., 76-B, 68 (1994).

12) J. L. Gilbert, C. A. Buckley, J. J. Jacobs, K. C. Bertin and M. R. Zernich : J. Bone and Joint Surg., 76-A, 110 (1994).

13) M. K. D. Benson, P. G. Goodwin and J. Brostoff : Br. Med. J., 15, 374 (1975).

14) 日本機会学会編 : 「生体材料学」, 初版, p.86, オー 厶社 (1993).

15) O. L. Huk, M. Bansal, F. Betts, C. M. Rimnac, J. R. Lieberman, M. H. Huo and E. A. Salvati : J. Bone and Joint Surg., 76B, 568 (1994).

16) H. C. Amstutz, P. Campbell, N. Kossovsky and I. C. Clarke : Clin. Orthop., [276] 7 (1992).

17) J. J. Callaghan, S. H. Dysart and C. G. Savory : J. Bone and Joint Surg., 70-A, 337 (1988).

18) P. K. Buchert, B. K. Vaughn, T. H. Mallory, C. A. Engh and J. D. Bobyn : J. Bone and Joint Surg., 68-A, 606 (1986).

19) S. D. Cook, E. A. Renz, R. L. Barrack, K. A. Thomas, A. F. Harding, R. J. Haddad and M. Milicic : Clin. Orthop., [194] 236 (1985).

20) H. G. French, S. D. Cook and R. J. Haddad : J. Biomed. Mater. Res., 18, 817 (1984).

21) R. Reuling, W. Wisser and A. Jung : $J$. Biomed. Mater. Res., 24, 979 (1990).

22）エクテサビ アリ, 大塚貴功, 坪井陽一 : 生体材 料, 13, 153 (1995).

23) H. J. Agins, N. W. Alcock, M. Bansal, E. A. Salvati, P. D. Wilson, P. M. Pellicci and P. G. Bullough : J. Bone and Joint Surg., 70-A, 347 (1988).

24) J. D. Witt and M. Swann : J. Bone and Joint Surg., 73-B, 559 (1991).

25) J. T. Scales : J. Bone and Joint Surg., 73-B, 534 (1991).

26) C. P. Case, V. G. Langkamer, C. James, M. R. Palmer, A. J. Kemp, P. F. Heap and L. Solomon : J. Bone and Joint Surg., 76-B, 701 (1994).

27) B. F. Shahgaldi, F. W. Heatley, A. Dewar and B. Corrin : J. Bone and Joint Surg., 77B, 962 (1995).

28) D. R. Haynes, S. D. Rogers, S. Hay, M. J. Pearcy and D. W. Howie : J. Bone and Joint Surg., 75-A, 825 (1993).

29) J.-M. Lee, E. A. Salvati, F. Betts, E. F. Dicarlo, S. B. Doty and P. G. Bullough : J. Bone and Joint Surg., 74-B, 380 (1992).

30) J. Goodfellow : J. Bone and Joint Surg., 74B, 645 (1992).

31) W. J. Gillespie, C. M. A. Frampton, R. J. Henderson and P. M. Ryan : J. Bone and Joint Surg., 70-B, 539 (1988).

32) J. J. Jacobs, D. H. Rosenbaum, R. M. Hay, S. Gitelis and J. Black : J. Bone and Joint Surg., 74-B, 740 (1992).
33) V. E. Dube and D. E. Fisher : Cancer, 30, 1260 (1972).

34) R. F. Coleman, J. Herrington and J. T. Scales : Br. Med. J., 3, 527 (1973).

35) J. Black, E. C. Maitin, H. Gelman and D. M. Morris : Biomaterials, 4, 160 (1983).

36) J. J. Jacobs, A. K. Skipor, J. Black, R. M. Urban and J. O. Galante : J. Bone and Joint Surg., 73-A, 1475 (1991).

37) D. A. Jones, H. K. Lucas, M. O'Driscoll, C. H. G. Price and B. Wibberley : J. Bone and Joint Surg., 57-B, 289 (1975).

38) G. Meachim and G. Brooke : Biomaterials, 4, 153 (1983).

39) H. S. Dobbs and M. J. Minski : Biomaterials, 1, 193 (1980).

40）副島利紀, 壇辻百合香, 永山存明: 生体の科学, 47, 248 (1996).

41) J. M. Anderson and K. M. Miller : Biomaterials, 5, 5 (1984).

42) 佐藤温重 : 病態生理, 3, 359 (1984).

43) T. Rae : J. Bone and Joint Surg., 57-B, 444 (1975).

44) T. Rae : J. Bone and Joint Surg., 63-B, 435 (1981).

45) S. M. Horowitz and J. B. Gonzales : Calcif. Tissue Int., 59, 392 (1996).

46) T. A. Blaine, R. N. Rosier, J. E. Puzas, R. J. Looney, P. R. Reynolds, S. D. Reynolds and R. J. O'Keefe : J. Bone and Joint Surg., 78-A, 1181 (1996).

47) W. A. Jiranek, M. Machado, M. Jasty, D. Jevsevar, H. J. Wolfe, S. R. Goldring, M. J. Goldberg and W. H. Harris : J. Bone and Joint Surg., 75-A, 863 (1993).

48）松野文夫 : 整・災外，32，1061（1989）。

49）小澤英浩, 江尻貞一, 中村浩彰 : 蛋白質核酸酵 素, 40, 492 (1995).

50) S. M. Horowitz, S. B. Doty, J. M. Lane and A. H. Burstein : J. Bone and Joint Surg., 75-A, 802 (1993).

51) S. R. Goldring, C. R. Clark and T. M. Wright: J. Bone and Joint Surg., 75-A, 799 (1993)

52) D. L. Coleman, R. N. King and J. D. Andrade: J. Biomed. Mater. Res., 8, 199 (1974).

53）井上昌幸，中山秀夫編：“歯科と金属アレル ギー”初版, p.161, デンタルダイヤモンド社 (1993).

54）中野ユミ子, 原一郎：産業医学, 24, 441 (1982).

55) H. F. Hildebrand, C. Veron and P. Martin : Biomaterials, 10, 545 (1989).

56) B. Alberts, D. Bray, J. Lewis, M. Raff, K. Roberts and J. D. Watson : Molecular Biology of the Cell”, 2nd. Ed., p.1046, Garland Publishing, Inc. (1989).

57) F. Sinigaglia: J. Invest. Dermatol., 102, 398 (1994)

58）安藤智博, 安藤順子 : 歯界展望, 88, 907 (1996).

59) P. A. Lalor, P. A. Revell, A. B. Gray, S. 
Wright, G. T. Railton and M. A. R. Freeman : J. Bone and Joint Surg., 73-B, 25 (1991).

60) G. C. Brown, M. D. Lockshin, E. A. Salvati and P. G. Bullough : J. Bone and Joint Surg., 59-A, 164 (1977).

61) M. K. D. Benson, P. G. Goodwin and J. Brostoff : Br. Med. J., 15, 374 (1975).

62) D. S. Halpin : J. Bone and Joint Surg., 57B, 451 (1975).

63) O. S. Svensson, E. B. Mathiesen, F. P. Reinholt and G. Blomgren : J. Bone and Joint Surg., 70-A, 1238 (1988).

64) M. B. Mayor, K. Merritt and S. A. Brown : Amer. J. Surg., 139, 477 (1980).

65) E. M. Evans, M. A. R. Freeman, A. J. Miller and B. Vernon-Roberts : J. Bone and Joint Surg., 56-B, 626 (1974).

66) H. G. French, S. D. Cook and R. J. Haddad: J. Biomed. Mater. Res., 18, 817 (1984).

67) A. G. Gristina: Science, [237] 1588 (1987).

68) A. G. Gristina, M. Oga, L. X. Webb and C. D. Hobgood : Science, [228] 990 (1985).

69）腰野富久, 青木茂夫 : 整形外科 MOOK, [56] 86 (1989).

70) J. Cordero, L. Munuera and M. D. Folgueira : J. Bone and Joint Surg., 76-B, 717 (1994).
71) S. Arens, U. Schlegel, G. Printzen, W. J. Ziegler, S. M. Perren and M. Hansis : $J$. Bone and Joint Surg., 78-B, 647 (1996).

72) P. M. Sullivan, R. C. Johnston and S. S. Kelley: J. Bone and Joint Surg., 72-A, 121 (1990).

73) D. A. Tannenbaum, L. S. Matthews and J. C. Grady-Benson : J. Bone and Joint Surg., 79-A，36 (1997).

74）遠藤一彦, 安彦善裕：まてりあ, 34, 1166 (1995).

75）佐々木佳男, 土居憲司, 松下富春：金属, 66, 812 (1996).

76) S. Morita, H. Yamamoto, K. Furuya, K. Ishihara and N. Nakabayashi : J. Biomed. Mater. Res., 34, 171 (1997).

77) L. Nordsletten, A. K. M. Hogasen, Y. T. Konttinen, S. Santavirta, P. Aspenberg and A. O. Asen: Biomaterials, 17, 1521 (1996).

78) T. Hanawa, H. Ukai and K. Murakami : $J$. Electron Spectrosc. Relat. Phenom., 63, 347 (1993).

79) T. Kawai, A. Mieki, Y. Ohno, M. Umemura, H. Kataoka, S. Kurita, M. Koike, T. Jinde, J. Hasegawa and M. R. Urist : Clin. Orthop., [290] 296 (1993).

80) K. Endo: Dent. Mater. J., 14, 185 (1995). 